\title{
Maximization of Seed Size Tuber Production in Early Bulking Potato (Solanum tuberosum L.) Variety Kufri Khyati
}

\author{
Murlidhar Sadawarti ${ }^{1 *}$, R. K. Singh ${ }^{2}$, R. K. Samadhiya ${ }^{1}$, S. P. Singh ${ }^{1}$, K. K. Pandey ${ }^{3}$, Satyajit Roy ${ }^{1}$ and S. K. Chakrabarti ${ }^{2}$ \\ ${ }^{1}$ ICAR-Central Potato Research Station, Gwalior, Madhya Pradesh (474 006), India \\ ${ }^{2}$ ICAR-Central Potato Research Institute, Himachal Pradesh (171 001), India \\ ${ }^{3}$ ICAR-Indian Institute of Vegetable Research Uttar Pradesh (221 305), India
}

\section{Corresponding Author}

Murlidhar Sadawarti

e-mail: murlidharsada@gmail.com

\author{
Article History \\ Article ID: $3 \mathrm{C0128}$ \\ Received in $14^{\text {th }}$ September, 2017 \\ Received in revised form $25^{\text {th }}$ November, 2017 \\ Accepted in final form $6^{\text {th }}$ December, 2017
}

\begin{abstract}
A field experiment was conducted at ICAR Central Potato Research Station Gwalior, MP, during 2015-16 and 2016-17 to study the effect of intra-row spacing, nitrogen levels and date of haulm killing on production of higher proportion of seed size tubers in early bulking variety Kufri Khyati. Treatments consisted of two intra-row spacing $(15 \mathrm{~cm}$ and $20 \mathrm{~cm})$, two dates of haulm killing (70 and 80 days) and two nitrogen levels (120 and $\left.150 \mathrm{~kg} \mathrm{ha}^{-1}\right)$. Treatments were replicated three times with split plot design. Germination percentage was significantly higher in $20 \mathrm{~cm}$ spacing (96.76\%) over $15 \mathrm{~cm}$ spacing (88.12\%). Non-significant differences were recorded among different parameters for growth attributes. Significantly highest seed size tuber and total tuber number was recorded in $\left.15 \mathrm{~cm} \mathrm{spacing} \mathrm{(405000} \mathrm{ha-1} \mathrm{and} 716000 \mathrm{ha}^{-1}\right)$ over $20 \mathrm{~cm}$ spacing ( $337000 \mathrm{ha}^{-1}$ and $605000 \mathrm{ha}^{-1}$ ) respectively. Non-significant but highest seed size tuber number (432000 ha-1 and 427000 $\mathrm{ha}^{-1}$ ) was recorded in $15 \mathrm{~cm}$ intra-row spacing $\times 80$ days haulm killing $\times 150 \mathrm{~kg} \mathrm{~N}$ and $15 \mathrm{~cm}$ intra - row spacing $\times 70$ days haulm killing $\times 120 \mathrm{~kg}$ $\mathrm{N}$ respectively. Seed size and total tuber yield $\left(\mathrm{t} \mathrm{ha}^{-1}\right)$ was in significantly higher $15 \mathrm{~cm}$ spacing $\left(22.44 \mathrm{t} \mathrm{ha}^{-1}\right.$ and $\left.33.16 \mathrm{t} \mathrm{ha}^{-1}\right) \mathrm{over}_{20 \mathrm{~cm}}$ spacing (19.81 tha-1 and $\left.29.84 \mathrm{t} \mathrm{ha}^{-1}\right)$. Significantly higher severe mosaic incidence $(0.87 \%)$ was observed with 80 days haulm killing over 70 days. Hence $15 \mathrm{~cm}$ intra - row spacing×70 days haulm killing×120 kg N was most suitable for getting higher proportion of seed size tubers in Kufri Khyati.
\end{abstract}

Keywords: Seed size tubers production, Kufri Khyati, potato

\section{Introduction}

As asexually/ vegetative propagated crop, potato is largely depend on tuber as seed than botanical seed like other crop and tubers are used as the primary reproductive unit and are referred as "Seed potatoes". Seed is the costliest input in potato production and accounts for about $40-50 \%$ of the cost of production (Sadawarti et al., 2017; Kushwah and Singh, 2011). Seed rate depends on the size of tubers used in planting for ware as well as seed crop. Standard seed tuber of 25-125 g weight recommended as seed size tubers (IMSCS, 2013). Potato tubers are planted either as whole unit (single- drop seed) or as cut seed. Cutting seed potatoes typically provides an economic advantage to growers, especially when tubers are too large to fit into a planter or to reduce seed cost. Though cut seed pieces reduce on seed cost but liable to get infected with viral diseases. Hence, demand for small seed tubers is high in seed market (Kushwah and Singh, 2008).

Kufri Khyati is a high yielding early maturing white tuber variety having moderate resistance to late blight and is for cultivation in plains of India. At most of the places, Kufri Khyati yielded higher than the other early maturing cultivars. An important feature of this variety is that, unlike most of the early maturing varieties, it possesses moderate resistance to late blight. This variety performs well both under very early (60 days) and early (75 days) harvests (Kumar et al., 2009a). This variety when cultivated for longer days up to 80 days produces large size tubers $>125 \mathrm{~g}$ (oversize) under seed production programme under standard N:P:K dose of 150:60:100 due to its very early bulking ability.

The tuber size profile can be reduced or expanded by altering inter and intra row seed spacing, controlling days of growth by planting late or killing vines/haulm early, regulating inputs like fertilizer and water, applying growth regulators, and manipulating seed tuber physiological age. Seed size influences the seed rate per hectare (Singh and Kushwah, 2010; Kumar et al., 2009b). The number of sprouts that develop from a seed tuber is influenced by the size of seed. Larger tubers generally produce more sprouts, but if larger seed is used, a greater weight of seed must be planted per unit 
area (Singh and Kushwah, 2010). Conversely, smaller seed ${ }^{-1}$ size tubers have more sprouts per unit weight than larger tubers, hence most farmers prefer to plant small tubers.

Hence present experiment was conducted to maximize the seed size tubers (25-125 g) with different combinations of fertilizers, halm killing date and planting geometry in extra early maturing variety Kufri Khyati.

\section{Materials and Methods}

A field experiment was conducted on fixed plots for two consecutive years in split plot design with cultivar Kufri Khyati at Central Potato Research Station $\left(26^{\circ} \mathrm{N}\right.$ and $78^{\circ} \mathrm{E}, 207 \mathrm{~m}$ above sea level and receives annual rainfall 400-800 mm), Gwalior, MP, during 2015-16 and 2016-17. The soil of the experimental field was silty clay loam having organic carbon $0.39 \%$, available N 125, P 41 and $\mathrm{K} 330 \mathrm{~kg} \mathrm{ha}^{-1}, \mathrm{pH} 7.0$ and EC $0.2 \mathrm{dS} \mathrm{m}^{-1}$, Cu 0.9 ppm, Zn 0.94 ppm, Fe 17 ppm and $\mathrm{Mg} 0.88$ ppm. Organic carbon content of soils is generally low because of high temperature in summers. Soil is heavy textured having high silt and clay contents. Treatments consisted of two intrarow seed spacing $(\mathrm{S} 1-15 \mathrm{~cm}, \mathrm{~S} 2-20 \mathrm{~cm})$ as main plot and two dates of haulm cutting (D1-70, D2-80) as sub plot and two nitrogen levels (N1-120 and N2-150 kg ha-1) as sub-sub plots. Treatments were replicated three times. Well sprouted seed tubers of cv. Kufri Khyati were planted on 2.11.2015 and 24.10.2016 during first and second years, respectively. Spacing for planting was kept at $60 \mathrm{~cm}$ as inter-row spacing. Fertilizer $\mathrm{P}$ and $\mathrm{K}$ were applied @ 60 and $100 \mathrm{~kg} \mathrm{ha}^{-1}$ respectively. Full doses of $\mathrm{P}$ and $\mathrm{K}$ and half dose of $\mathrm{N}$ were applied at the time of planting and remaining half dose of $\mathrm{N}$ was applied through urea at the time of earthing up which was done 25 days after planting (DAP). At planting, half dose of nitrogen with full dose of phosphorus and potassium were applied through ammonium sulphate, single super phosphate and muriate of potash, respectively. Haulm killing was done on 70 and 80 days after planting during first and second years, respectively. Overall, 4 irrigations were applied in 2015 in 2016 accounting winter rains. Plants infected with viruses (severe and mild mosaics) were got recorded. Haulm cutting was done at respective dates after 70 and 80 days after planting as per treatment. To control late blight, Dithane M-45 was sprayed @ $0.2 \%$ at 60 days stage of crop growth. As per standard seed production practices, Imidacloprid, trizophos and Tiamithoxom were sprayed alternatively at 10 days interval starting from emergence of crop until 10 days before haulm cutting. Tubers were harvested 20 days after haulm cutting on hardening of tuber skin. Observations on crop growth and yield attributes were recorded at 50 DAP and at harvest of the crop. Data were pooled and analysed statistically and means were separated according to the least significant differences (LSD) at 0.05 level of probability.

\section{Results and Discussion}

\subsection{Growth attributes}

Normal planting resulted in significantly higher germination percentage (96.76) over closer intra spacing (88.12), but no significant differences was recorded in halum killing dates and nitrogen doses. No significant difference was recorded in number of stem and compound leaves plant ${ }^{-1}$, plant height and vigour (scale 1-5) among intra row spacing and haulm killing dates. Similar trend was recorded for nitrogen doses except for compound leaves where N @ $120 \mathrm{~kg} \mathrm{ha}^{-1}$ (66.7) recorded significantly higher than N @ $150 \mathrm{~kg} \mathrm{ha}^{-1}$ (59.3) Table 1. None of the interactions among intra-spacing, halum killing dates and $\mathrm{N}$ doses found to be significant in the present study for growth attributing parameters. These results are in conformity with Singh and Bhatnagar (2014).

\subsection{Health standard}

Intra- row spacing did not show any significant effect on off type mild mosaic and severe mosaic incidence. Similar trend was recorded for $\mathrm{N}$ doses. Significantly higher severe and mild mosaic incidence was observed with 80 days haulm cut $(0.87 \%)$ over 70 days haulm cut $(0.42 \%)$. Interaction of spacing $\times \mathrm{N}$ levels and days to haulm cut were not found significant (Table 1). Singh and Kushwah (2008) also reported similar results.

\subsection{Yield attributes}

There was no any significant effect of intra-row spacing on yield of under size and over size seed tuber number ha-1. Significantly higher seed size (405000 ha-1) and total tuber (702000 ha-1) number was recorded with closer intra row spacing of $15 \mathrm{~cm}$ over $20 \mathrm{~cm}$ intra-row spacing (337000 ha-1 seed size and 605000 ha-1 $^{-1}$ total tuber) Table 2. Narrower distance increases undersize and small tubers (Akasa et al., 2014). Tubers, under stressed plants may actually bulk sooner and faster than those under healthy, unstressed plants. However, this usually occurs at the expense of canopy development. There was no any significant effect of days of haulm cut on production of under size and seed size tubers. Kumar et al., 2009a also reported similar results. Significantly higher over size tubers were recorded with 80 days haulm cut over 70 days haulm cut. No significant differences were reported for any category of tubers for $\mathrm{N}$ doses treatments for tuber numbers ha-1 ${ }^{-1}$ In interaction study, no significant differences was recorded among intra-spacing, halum killing dates and $\mathrm{N}$ doses for any category of tubers, non-significant but highest seed size tuber number (432 thousend ha-1 and 427 thousand ha-1) was recorded in $15 \mathrm{~cm}$ intra-row spacing $\times 80$ days haulm killing $\times 150 \mathrm{~kg} \mathrm{~N}$ and $15 \mathrm{~cm}$ intra-row spacing $\times 70$ days haulm killing $\times 120 \mathrm{~kg} \mathrm{~N}$ respectively.

Similar trend was recorded in seed tuber yield $\left(\mathrm{t} \mathrm{ha}^{-1}\right)$ wherein significantly higher seed size $\left(22.44 \mathrm{t} \mathrm{ha}^{-1}\right)$ and total tuber (33.16 $\mathrm{t} \mathrm{ha}^{-1}$ ) tuber yield was recorded with closer intra row spacing of $15 \mathrm{~cm}$ over $20 \mathrm{~cm}$ intra-row spacing (19.81 t ha-1 seed size and $29.84 \mathrm{t} \mathrm{ha}^{-1}$ total tuber) Table 2 . Similar result of highest total tuber yield in closer spacing of $50 \times 10 \mathrm{~cm}^{2}$ under Bangladesh conditions (Al Mamun et al., 2016). The 


\begin{tabular}{|c|c|c|c|c|c|c|c|c|}
\hline Treatments & $\begin{array}{c}\text { Germina- } \\
\text { tion } \%\end{array}$ & $\begin{array}{c}\text { Plant } \\
\text { height }(\mathrm{cm})\end{array}$ & $\begin{array}{l}\text { leaves } \\
\text { plant }^{-1}\end{array}$ & $\begin{array}{l}\text { stem } \\
\text { plant }^{-1}\end{array}$ & $\begin{array}{c}\text { Vigour } \\
\text { Scale (1-5) }\end{array}$ & $\begin{array}{l}\text { Off type } \\
(\%)\end{array}$ & $\begin{array}{l}\text { Mild mo- } \\
\text { saic (\%) }\end{array}$ & $\begin{array}{c}\text { Severe } \\
\text { mosaic (\%) }\end{array}$ \\
\hline \multicolumn{9}{|l|}{ Spacing } \\
\hline $\mathrm{S}-1(15 \mathrm{~cm})$ & 88.12 & 29 & 60.5 & 4.9 & 4.5 & 0.03 & 0.69 & 0.73 \\
\hline $\mathrm{S}-2(20 \mathrm{~cm})$ & 96.76 & 28 & 65.4 & 5.2 & 4.7 & 0.05 & 0.56 & 0.56 \\
\hline SEm \pm & 0.73 & 0.7 & 4.45 & 0.33 & 0.08 & 0.04 & 0.12 & 0.07 \\
\hline $\mathrm{CD}(p=0.05)$ & 2.52 & NS & NS & NS & NS & NS & NS & NS \\
\hline \multicolumn{9}{|c|}{ Days to halum killing } \\
\hline (D-1) 70 days & 92.44 & 29 & 60.5 & 4.8 & 4.5 & 0.05 & 0.52 & 0.42 \\
\hline D-2 (80 days) & 93.21 & 28 & 65.5 & 5.3 & 4.7 & 0.03 & 0.73 & 0.87 \\
\hline SEm \pm & 0.73 & 0.7 & 4.45 & 0.33 & 0.08 & 0.04 & 0.12 & 0.07 \\
\hline $\mathrm{CD}(p=0.05)$ & NS & NS & NS & NS & NS & NS & NS & 0.26 \\
\hline \multicolumn{9}{|c|}{ N level $\left(\mathrm{kg} \mathrm{ha}^{-1}\right)$} \\
\hline $\mathrm{N}-1(120)$ & 92.66 & 29 & 66.7 & 5.1 & 4.7 & 0.03 & 0.62 & 0.62 \\
\hline N2-(150) & 92.99 & 28 & 59.3 & 4.9 & 4.5 & 0.05 & 0.63 & 0.66 \\
\hline SEm \pm & 0.97 & 0.9 & 2.05 & 0.23 & 0.07 & 0.04 & 0.07 & 0.11 \\
\hline$C D(p=0.05)$ & NS & NS & 6.69 & NS & NS & NS & NS & NS \\
\hline \multicolumn{9}{|l|}{ Interaction } \\
\hline S1D1 N1 & 89.03 & 30 & 57.8 & 4.7 & 4.2 & 0.00 & 0.83 & 0.55 \\
\hline S1D1 N2 & 87.22 & 29 & 52.3 & 4.4 & 4.3 & 0.00 & 0.70 & 0.55 \\
\hline S1D2 N1 & 90.70 & 30 & 68.0 & 5.3 & 5.0 & 0.14 & 0.56 & 0.83 \\
\hline S1D2N2 & 88.61 & 27 & 64.0 & 5.0 & 4.5 & 0.00 & 0.69 & 0.97 \\
\hline S2D1 N1 & 95.18 & 30 & 70.5 & 5.0 & 5.0 & 0.00 & 0.19 & 0.37 \\
\hline S2D1 N2 & 98.33 & 26 & 61.2 & 5.2 & 4.7 & 0.19 & 0.37 & 0.19 \\
\hline S2D2 N1 & 95.74 & 27 & 70.3 & 5.5 & 4.7 & 0.00 & 0.93 & 0.74 \\
\hline S2D2N2 & 97.78 & 29 & 59.5 & 5.2 & 4.5 & 0.00 & 0.74 & 0.93 \\
\hline SEm \pm & 1.94 & 1.9 & 4.11 & 0.45 & 0.14 & 0.08 & 0.14 & 0.22 \\
\hline$C D(p=0.05)$ & NS & NS & NS & NS & NS & NS & NS & NS \\
\hline \multicolumn{9}{|c|}{ Table 2: Effect of different treatments on yield attributes } \\
\hline & \multicolumn{4}{|c|}{ Tuber number ('000/ha) } & \multicolumn{4}{|c|}{ Tuber weight $\left(\mathrm{t} \mathrm{ha}^{-1}\right)$} \\
\hline Treatments & $\begin{array}{l}\text { Under size } \\
(<25 \mathrm{~g})\end{array}$ & $\begin{array}{l}\text { Seed size } \\
(25-125 \mathrm{~g})\end{array}$ & $\begin{array}{l}\text { Over size } \\
(>125 \mathrm{~g})\end{array}$ & Total & $\begin{array}{l}\text { Under size } \\
(<25 \mathrm{~g})\end{array}$ & $\begin{array}{l}\text { Seed size } \\
(25-125 \mathrm{~g})\end{array}$ & $\begin{array}{c}\text { Over size } \\
(>125 \mathrm{~g})\end{array}$ & Total \\
\hline \multicolumn{9}{|l|}{ Spacing } \\
\hline S-1 $(15 \mathrm{~cm})$ & 265 & 405 & 46 & 716 & 2.32 & 22.44 & 8.41 & 33.16 \\
\hline $\mathrm{S}-2(20 \mathrm{~cm})$ & 224 & 337 & 44 & 605 & 1.78 & 19.81 & 8.24 & 29.84 \\
\hline SEm \pm & 16.8 & 13.5 & 2.5 & 27.7 & 0.12 & 0.64 & 0.41 & 0.67 \\
\hline $\operatorname{CD}(p=0.05)$ & NS & 46.6 & NS & 95.6 & 0.42 & 2.22 & NS & 2.30 \\
\hline \multicolumn{9}{|c|}{ Days to halum killing } \\
\hline (D-1) 70 days & 251 & 359 & 38 & 648 & 2.27 & 21.61 & 7.00 & 30.88 \\
\hline D-2 (80 days) & 238 & 383 & 51 & 673 & 1.83 & 20.65 & 9.65 & 32.13 \\
\hline SEm \pm & 16.8 & 13.5 & 2.5 & 27.7 & 0.12 & 0.64 & 0.41 & 0.67 \\
\hline
\end{tabular}




\begin{tabular}{|c|c|c|c|c|c|c|c|c|}
\hline \multirow[b]{2}{*}{ Treatments } & \multicolumn{4}{|c|}{ Tuber number ('000/ha) } & \multicolumn{4}{|c|}{ Tuber weight $\left(\mathrm{t} \mathrm{ha}^{-1}\right)$} \\
\hline & $\begin{array}{c}\text { Under size } \\
(<25 \mathrm{~g})\end{array}$ & $\begin{array}{l}\text { Seed size } \\
(25-125 \mathrm{~g})\end{array}$ & $\begin{array}{l}\text { Over size } \\
(>125 \mathrm{~g})\end{array}$ & Total & $\begin{array}{l}\text { Under size } \\
(<25 \mathrm{~g})\end{array}$ & $\begin{array}{l}\text { Seed size } \\
(25-125 \mathrm{~g})\end{array}$ & $\begin{array}{c}\text { Over size } \\
(>125 \mathrm{~g})\end{array}$ & Total \\
\hline $\mathrm{CD}(p=0.05)$ & NS & NS & 8.7 & NS & 0.42 & NS & 1.40 & NS \\
\hline \multicolumn{9}{|c|}{$\mathrm{N}$ level $\left(\mathrm{kg} \mathrm{ha}^{-1}\right)$} \\
\hline N-1 (120) & 239 & 373 & 44 & 656 & 1.99 & 21.23 & 8.19 & 31.41 \\
\hline N2-(150) & 251 & 369 & 46 & 666 & 2.11 & 21.02 & 8.46 & 31.59 \\
\hline SEm \pm & 14.2 & 11.9 & 1.6 & 21.7 & 0.10 & 0.68 & 0.30 & 0.83 \\
\hline $\mathrm{CD}(p=0.05)$ & NS & NS & NS & NS & NS & NS & NS & NS \\
\hline \multicolumn{9}{|l|}{ Interaction } \\
\hline S1D1 N1 & 270 & 427 & 35 & 732 & 2.63 & 23.69 & 6.27 & 32.58 \\
\hline S1D1 N2 & 287 & 377 & 46 & 710 & 2.65 & 23.13 & 8.59 & 34.38 \\
\hline S1D2 N1 & 227 & 386 & 49 & 662 & 1.79 & 21.46 & 9.03 & 32.28 \\
\hline S1D2N2 & 276 & 432 & 52 & 760 & 2.18 & 21.49 & 9.73 & 33.41 \\
\hline S2D1 N1 & 199 & 318 & 40 & 557 & 1.73 & 19.76 & 7.73 & 29.22 \\
\hline S2D1 N2 & 249 & 313 & 31 & 593 & 2.07 & 19.85 & 5.40 & 27.32 \\
\hline S2D2 N1 & 260 & 361 & 51 & 671 & 1.81 & 20.02 & 9.73 & 31.57 \\
\hline S2D2N2 & 191 & 355 & 53 & 598 & 1.52 & 19.62 & 10.12 & 31.25 \\
\hline SEm \pm & 28.5 & 23.7 & 3.2 & 43.4 & 0.19 & 1.37 & 0.59 & 1.66 \\
\hline $\mathrm{CD}(p=0.05)$ & NS & NS & NS & NS & NS & NS & 1.92 & NS \\
\hline
\end{tabular}

highest yield at the closest spacing might have been due to the presence of the greatest number of plants. Foliage coverage increased with an increase in the plant density which was found to be related to higher tuber yield (Bremner and Radley, 1966). Mahmud et al. (2012) reported closer spacing increased the yield and that a higher foliage coverage percentage increased the yield by increasing the leaf area index and the photosynthetic area which favours production and the accumulation of more photosynthates in the tuber.

Significantly higher over size tubers were recorded with 80 days haulm cut ( $9.65 \mathrm{t} \mathrm{ha}^{-1}$ ) over 70 days haulm cut $(7.00$ $\left.\mathrm{t} \mathrm{h} \mathrm{a}^{-1}\right)$. In interaction study, no significant differences were recorded among intra-spacing, halum killing dates and $\mathrm{N}$ doses for any category of tubers. N @ $125 \mathrm{~kg} \mathrm{ha}^{-1}$ was beneficial for cultivation than recommended dose of N@150 kg ha-1 (Yadu et al., 2013). Bishop and Wright (1959) reported that potato size was determined more by spacing than by seed piece size. Too much nitrogen early in the season may promote excessive foliar growth and delay tuberization, limiting the available window for bulking and resulting in reduced yield over the available growing season (Knowles et al., 2013). It is well known that lower dose of nitrogen will generally set tubers early and produce less foliar growth and result in early foliar senescence, tuber maturity.

\section{Conclusion}

70 days seed crop have significantly lower virus incidence.
Growth attributes are at par for spacing distance, days to halum cut and $\mathrm{N}$ doses. For getting higher proportion of seed size tubers, $15 \mathrm{~cm}$ intra-row spacing $\times 70$ days haulm killingx $120 \mathrm{~kg} \mathrm{~N}$ found to be most suitable combinations in seed production system of Kufri Khyati.

\section{References}

Akasa, B., Belew, D., Debela, A., 2014. Yield and quality of potato (Solanum tuberosum L.) seed tuber as influenced by inter and intra row spacing at Bako, Western Ethopia. Journal of Biological Sciences 14(6), 431-435.

Al Mamun, Md. A., Al-Mahmud, A., Zakaria, M., Hossain, M., Hossain, M., Tofazzal, M., 2016. Effects of planting times and plant densities of top-shoot cuttings on multiplication of breeder seed potato. Agriculture and Natural Resources 50, 26-31.

Bishop, J.C., Wright, D.N., 1959. The effect of size and spacing of seed pieces on the yield and grade of white rose potatoes in Kern Country, California. American Potato Journal 36(7), 235-240.

Bremner, P.M., Radley, R.W., 1966. Studies in potato agronomy II. The effect of variety, seed size and spacing on growth, development and yield. Journal of Agricultural Science. Cambridge 66, 253-262.

IMSCS, 2013. The Central Seed Certification Board Department of Agriculture \& Co-operation Ministry of Agriculture Government of India, New Delhi, 2013, 340-344. 
Knowles, N.R., Knowles, L.O., Pavek, M.J., 2013. In season management and post-harvest management and post-harvest quality-lessions learned from Alpine, Sage Russet and other cultivars. In : Proceedings of the Washington -Oregon Potato Conference, 29-31, January, Kanneewich, Washington State Potato Commission, Moses Lake, Washington, 34-47.

Kumar, R., Kang, G.S., Pandey, S.K., Gopal, J., 2009a. Kufri khyati: a new early maturing potato variety for Indian plains. Potato Journal 36 (1-2), 14-19.

Kumar, V., Vyakarnahal, B.S., Basavaraj, N., 2009b. Effect of seed tuber size and dates of haulm killing on growth and yield of seed potato crop. Potato Journal 36 (1-2), 45-50.

Kushwah, V.S., Singh, S.P., 2008. Effect of intra-row spacing and date of haulm cutting on production of small tubers. Potato Journal 35(1-2), 88-90.

Kushwah, V.S., Singh, S.P., 2011. Relative performance of low input and high input technology for potato production in India. Potato Journal 38(1), 56-60.

Mahmud, A.A., 2012. Improvement of Drought Tolerant Potato Variety (Ph.d. Dissertation). Department of Horticulture, Bangabandhu Sheikh Mujibur Rahman Agricutural
University, Salna, Gazipur, Bangladesh.

Sadawarti, M.J., Singh, S.P., Sharma, S.K., Samadhiya, R.K., Singh, R.K., Roy, S., Chakrabarti, S.K., 2017. Madhya Pradesh ke Gwalior-Chambal Sambhag me alubeejkisambhwanaye. http://www.krishisewa.com/ articles/seed-production/789-madhya-pradesh-potatoseed-production.html.

Singh, S.P., Bhatnagar, A., 2014. Effect of different size of seed tubers on production of small seed tubers. Progressive Horticulture 46(1), 98-101.

Singh, S.P., Kushwah, V.S., 2010. Effect of size of seed tubers and date of haulm cuttings on production of small seed tubers. Potato Journal 37(3\&4), 167-170.

Singh, S.P., Kushwah, V.S., 2008. Effect of prolonged use of small sized tubers on mosaic incidence, yield and other growth parameters. Potato Journal 35(1-2), 91-93.

Yadu, D., Sarnaik, D.A., Dewangan, S.R., Suryawanshi, V.K., 2013. Effect of Varying Levels of NPK Fertilizers and Size of Seed Tubers on Growth and Yield of Potato (Solanum tuberosum L.) in Alfisol. Indian Horticulture Journal 3(3/4), 88-90. 